\title{
Investigation of Mechanical Properties of Horn Powder-Filled Epoxy Composites
}

\author{
Duraisamy Kumar ${ }^{1,}{ }^{*}$ - Sadayan Rajendra Boopathy ${ }^{2}$ - Dharmalingam Sangeetha ${ }^{2}$ - Govindarajan Bharathiraja ${ }^{1}$ \\ ${ }^{1} \mathrm{C}$. Abdul Hakeem College of Engineering and Technology, Department of Mechanical Engineering, India \\ ${ }^{2}$ College of Engineering Guindy, Anna University, Department of Mechanical Engineering, India
}

Recent environmental concerns focus on the development of bio-composites, due to their low cost, and eco-friendly and bio-degradability characteristics. The aim of this work is to investigate the properties of particle-filled composites fabricated using bio-waste horn powder (HP) and epoxy resin. Composites were fabricated according to a Taguchi $L_{9}(3 \times 3)$ orthogonal array. The HP particles and matrix were mixed in an appropriate ratio, compression-moulded and cured at room temperature to produce the specimens. Properties, such as ultimate tensile strength, tensile modulus, elongation percentage at break, flexural strength, flexural modulus, impact strength and microstructure of the specimens, were investigated. Scanning electron microscopy (SEM) micrographs of tensile tested specimens show good compatibility between HP particles and resin, when the HP volume is at $10 \%$ and increases in agglomeration with increase in the HP volume percentage. Optimization of factors was done using grey relational analysis (GRA) and analysis of variance (ANOVA). The optimum factor levels were found to be the highest $\mathrm{NaOH}$ concentration (con.), $A_{3}$ (i.e., $0.3 \mathrm{~N}$ ), the smallest HP size, $B_{1}$ (i.e., $125 \mu \mathrm{m}$ ) and the lowest HP volume percentage, $C_{1}$ (i.e., $10 \%$ ). The contribution of influencing factors in decreasing order were found to be, HP volume percentage with $90.87 \%$, HP size with $6.43 \%$ and $\mathrm{NaOH}$ concentration with $0.78 \%$. From the $\mathrm{R}$ squared and $\mathrm{R}$ squared adjusted values of the properties, it is determined that most of the values are above $95 \%$, confirming a $95 \%$ confidence level. Comparison between the optimum specimen and untreated HP specimens reveals that the optimum specimen has better properties. Hence, HP/epoxy composites can find application in various sectors.

Keywords: horn powder, epoxy resin, particulate composites, mechanical properties, optimization.

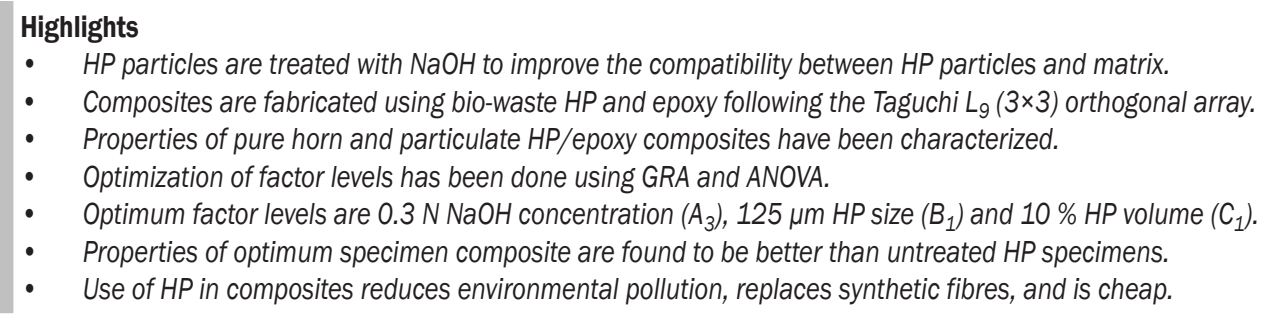

0 INTRODUCTION

Polymeric composite materials are used in the automotive, marine, electrical, industrial, construction, house-hold appliances and sports goods fields due to their light weight, high strength, stiffness and corrosion resistance. Recently, extensive research work has been carried out on the natural fibre reinforced composite materials due to their abundant availability and low cost. Natural fibres such as kenaf, hemp, flax, jute, banana, sisal, bamboo, etc., are obtained from plants. Fibres, such as silk, feather, wool, etc., are obtained from animals. Horns are found in the heads of ox, buffalo, sheep, goat, etc. and are never branched. Horns are found in various shapes, length and curvature. These are made of a structural protein called keratin that is strong and rigid. Hard keratins have high sulphur content and are classified into two groups, $\alpha$-keratin found in mammals, such as hair, horns, nails, etc. and $\beta$-keratin found in avian and reptilian tissues. Oxen horn is one of the by-products of slaughter houses. The central core of the horn turned into cylindrical form is used for manufacturing useful items. Horn chips of this process become landfill and cause environmental pollution. These chips can be used as filler for manufacturing composite materials. Epoxies are cross linked thermosetting materials, which cannot be recycled. Araldite LY 556 is medium viscosity, unmodified liquid epoxy resin based on Bisphenol-A. They are stable to chemical attacks and are excellent adherents, having slow shrinkage during curing and no emissions of volatile gases. High bonding strength and room temperature curing makes it commonly selected as a matrix material. Aradur, the hardener used with Araldite has the designation HY 951. The mixing ratio between resin and hardener is 100:10 parts by weight.

Sisson has briefly summarized the structure of horn [1]. Meyers et al. have discussed the structure and mechanical properties of biological materials [2]. 
Rizvi and Khan have investigated the frequency and temperature dependence of dielectric constant and loss factor in cow horn keratin [3]. Kumar and Boopathy have studied mechanical and thermal properties of defatted oxen horn fibre reinforced PP composites and observed that $15 \%$ of horn fibre particles gave optimum results [4]. Venkateshwaran et al. have modified the fibre surface and found that $1 \% \mathrm{NaOH}$ treated fibre-reinforced composites behave superior than other treated and untreated fibre composites, and high concentrations of alkali damages the fibre and decreases mechanical properties [5]. Fu et al. have reviewed the effects of particle size, particle/ matrix interface adhesion and particle loading on the stiffness, strength and toughness of particulatepolymer composites [6]. Ku et al. have reviewed the tensile properties of various plant-based natural fibre reinforced polymer composites [7]. Mishra et al. have investigated the mechanical properties of alkalitreated chicken feather reinforced epoxy composites and found that the interface bonding between the matrix and the reinforcement is beneficial due to the formation of ester and amine groups [8]. Girisha et al. have investigated the effect of water absorption on the mechanical properties of sisal and coconut coir-reinforced epoxy composites and found that exposure to moisture caused a significant drop in the mechanical properties due to the degradation of the fibre-matrix interface [9]. Blau has presented a survey of compositions, functions and testing of commercial friction brake materials and their additives [10]. Deo and Acharya have studied abrasive wear behaviour of Lantana-Camara Fibre reinforced epoxy composites and observed that the optimum wear reduction was obtained when the fibre content is 40 weight \% [11]. Olokode et al. have studied the synergistic effects of friction materials with cow hoof dust and bagasse and observed that friction material with $100 \mu \mathrm{m}$ size gave better results than other sizes [12]. Antaryami has investigated the wear characteristics of teak wood dust-filled epoxy composites and found that the composite with $10 \%$ wood dust may be more suitable for frictional applications [13]. Zhan et al. have investigated the properties of composites with epoxy, chicken feather fibre and E-glass fibres and found that the composites can be used as printed circuit boards [14]. Mishra and Nayak have investigated the dielectric properties of chicken feather-reinforced epoxy matrix composites and found that the dielectric properties are dependent on operating frequency and temperature conditions [15]. Krishnaiah and Shahabudeen have found that grey relational analysis is an accurate method for solving interrelationship among multiple responses in engineering problems. Analysis of variance is a method of dividing variation in an experiment into distinct components and the related degree of freedom. The frequency test (F-test) is employed to analyse and identify the significant effects of the parameters affecting the performance measures [16]. Fung has proposed grey relational analysis based on the Taguchi method's response table for the optimization of manufacturing processes for the wear property of fibre-reinforced polybutylene terephthalate composites [17]. Hasani et al. have used grey relational analysis to optimize the process parameters of open-end spinning system with multiple performance characteristics and found that the integration of grey relational analysis and the Taguchi method can be applicable for the optimization of process parameters and help to improve process efficiency [18]. Sui et al. have prepared cancun natural sand-filled epoxy composites and characterized thermal and mechanical properties of the composites containing up to 5 weight percentage of the sand particles and found that the highest flexural strength appears in the epoxy composite containing 1 weight percentage of sand particles [19]. Ozsoy et al. have studied the influence of micro-fillers $\mathrm{Al}_{2} \mathrm{O}_{3}, \mathrm{TiO}_{2}$ and fly ash added in 10 weight percentage to 30 weight percentage; the nano-fillers $\mathrm{Al}_{2} \mathrm{O}_{3}, \mathrm{TiO}_{2}$ and clay added in 2.5 weight percentage to 10 weight percentage on the mechanical properties of epoxy matrix composites. The results show that the tensile strength, flexural strength and elongation percentage at break values of composites decreased while the tensile modulus and flexural modulus increased with the increase in micro and nano-filler content [20]. Croccolo et al. have compared the mechanical properties of flax fibre/isophthalic resin composites and flax fibre/vinyl ester resin composites and found that isophthalic resin composites have better properties than vinyl ester resin composites do [21]. Valasek and Muller have described "two-body" abrasive wear on an abrasive cloth and a "three-body" abrasive wear on a machine with a rubber disc using sand abrasion and showed that there is no clear correlation between the two and three-body abrasions as far as the volume decrease is concerned [22]. Valasek and Muller have studied the abrasive wear resistance and hardness of waste corundum particle/epoxy composites with waste $\mathrm{Al}_{2} \mathrm{O}_{3}$ as filler and found that wear resistance and hardness have increased due to the inclusion of corundum [23].

The objective of this work is to develop a biowaste HP-filled epoxy composite. Surface treatment of natural fibres using alkali $(\mathrm{NaOH})$ solution overcomes 
the difficulty of incompatibility between hydrophilic fibres and hydrophobic matrix. Optimization of factor levels for multiple quality responses like composite materials is very difficult. Optimum levels of parameters were obtained by fabricating the composites using Taguchi $\mathrm{L}_{9}(3 \times 3)$ orthogonal array and optimizing using GRA and ANOVA. GRA transforms multiple quality characteristics into grey relational grades. By comparing the grey relational grades, the arrays of respective quality characteristics are obtained in accordance with response grades to select an optimal set of process parameters. Apart from these nine compositions, specimens were also made with $20 \%$ untreated HP and $80 \%$ matrix and with neat epoxy. Mechanical and surface morphological properties of these composites were characterized and compared with the properties of specimens made of untreated HP and neat epoxy.

\section{MATERIALS AND METHOD}

\subsection{Materials}

HP chips used as fillers were obtained from a buttonmanufacturing factory near Ambur, Tamilnadu, India. Sodium Chloride Extrapure used to clean the HP particulates was obtained from S D FineChem Limited, Mumbai, India. Diethyl Ether (Ether Solvent) used to de-fat the HP was obtained from Nice Chemicals (P) Ltd., Kochi, India. Sodium Hydroxide Flakes used to treat the HP surfaces was obtained from Qualikems Fine Chem Pvt. Ltd., Vadodara, India. Araldite LY 556 used as resin and Aradur HY 951 used as hardener were obtained from Huntsman Advanced Materials India Private Limited, Mumbai, India.
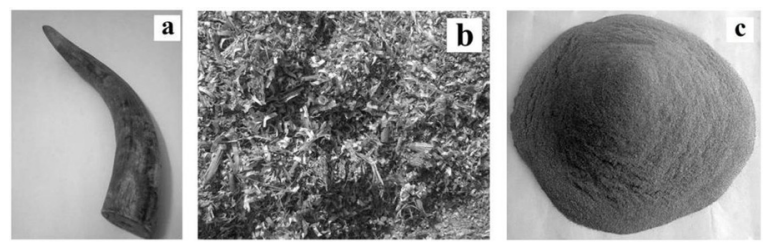

Fig. 1. a) An ox horn, b) horn chips thrown as landfill and c) particles of HP sieved to a desired size

\subsection{HP Processing}

Fig. 1a shows an ox horn. Fig. 1b shows horn chips as landfill. HP chips were washed in water thoroughly, dried, ground into particulates using double bladed electrical grinder and sieved to $+125 \mu \mathrm{m},+250 \mu \mathrm{m}$ and $+425 \mu \mathrm{m}$ sieve grades using a sieve shaker. Fig. $1 \mathrm{c}$ shows particles sieved to the desired size. The HP particles were washed in 0.1 Normality (N) $\mathrm{NaCl}$ solution for eight hours by changing the solution periodically after every two hours. They were washed in water, dried and immersed in diethyl ether for four hours to remove fat. Then they we rewashed in water thoroughly and dried. The defatted HP particles were treated with $0.1 \mathrm{~N}, 0.2 \mathrm{~N}$ and $0.3 \mathrm{~N} \mathrm{NaOH}$ solutions for four hours, washed thoroughly in water and dried.

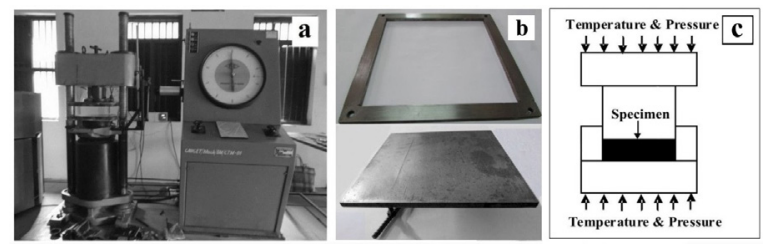

Fig. 2. a) Hydraulic compression machine with dies fixed on table and crosshead, b) intermediate die with mould cavity and punch set, and c) manufacturing procedure of plate specimens

\subsection{Specimen Preparation}

Fig. 2a shows the hydraulic compression machine with dies fixed on its table and crosshead. Fig. 2b shows the intermediate die with mould cavity and punch set. Fig. 2c shows the manufacturing procedure of plate specimens. Plates of size $290 \mathrm{~mm} \times 290$ $\mathrm{mm} \times 4.5 \mathrm{~mm}$ were prepared following Taguchi $\mathrm{L}_{9}$ orthogonal array with three factors and three levels as shown in Table 1 and with untreated HP and epoxy. The details of ingredients used are shown in Table 2. Required amount of resin and hardener were weighed using an electronic weighing balance of accuracy $0.001 \mathrm{~g}$ and mixed to get a homogeneous mixture of matrix. The surfaces and walls of a selffabricated compression moulding dies were applied with release agent for easy removal of the moulded plate specimen. Required amount of HP was weighed and mixed with the matrix thoroughly. The mixture was transferred to the die and pressed at a pressure of $0.5 \mathrm{MPa}$ for 30 minutes. The plates were post-cured at room temperature for 24 hours in clamped condition. The plates were allowed to rest in ambient conditions for one week. Test specimens were cut from the plate according to ASTM standards and the surfaces

Table 1. Input factors for Taguchi $L_{9}$ orthogonal array

\begin{tabular}{lccc}
\hline Factors & Level 1 & Level 2 & Level3 \\
\hline NaOH con. $(\mathrm{A})[\mathrm{N}]$ & 0.1 & 0.2 & 0.3 \\
\hline HP size $(\mathrm{B})[\mu \mathrm{m}]$ & 125 & 250 & 425 \\
\hline HP vol. $(\mathrm{C})[\%]$ & 10 & 20 & 30 \\
\hline
\end{tabular}


were prepared with an emery sheet of 150 grit size. Fig. 3 shows the tensile test specimen, flexural test specimen, and impact test specimen.

Table 2. Details of ingredients used

\begin{tabular}{|c|c|c|c|c|c|}
\hline \multicolumn{4}{|c|}{$\mathrm{HP}$} & \multirow{2}{*}{$\begin{array}{c}\text { Matrix } \\
\text { Vol. } \\
{[\%]}\end{array}$} & \multirow{2}{*}{$\begin{array}{c}\text { Total Vol } \\
{[\%]}\end{array}$} \\
\hline Trial ID & $\begin{array}{l}\mathrm{NaOH} \text { con. } \\
{[\mathrm{N}]}\end{array}$ & $\begin{array}{c}\text { Particle size } \\
{[\mu \mathrm{m}]}\end{array}$ & $\begin{array}{l}\text { Vol. } \\
{[\%]}\end{array}$ & & \\
\hline$A_{1} B_{1} C_{1}$ & 0.1 & 125 & 10 & 90 & 100 \\
\hline $\mathrm{A}_{1} \mathrm{~B}_{2} \mathrm{C}_{2}$ & 0.1 & 250 & 20 & 80 & 100 \\
\hline $\mathrm{A}_{1} \mathrm{~B}_{3} \mathrm{C}_{3}$ & 0.1 & 425 & 30 & 70 & 100 \\
\hline $\mathrm{A}_{2} \mathrm{~B}_{1} \mathrm{C}_{2}$ & 0.2 & 125 & 20 & 80 & 100 \\
\hline $\mathrm{A}_{2} \mathrm{~B}_{2} \mathrm{C}_{3}$ & 0.2 & 250 & 30 & 70 & 100 \\
\hline $\mathrm{A}_{2} \mathrm{~B}_{3} \mathrm{C}_{1}$ & 0.2 & 425 & 10 & 90 & 100 \\
\hline $\mathrm{A}_{3} \mathrm{~B}_{1} \mathrm{C}_{3}$ & 0.3 & 125 & 30 & 70 & 100 \\
\hline $\mathrm{A}_{3} \mathrm{~B}_{2} \mathrm{C}_{1}$ & 0.3 & 250 & 10 & 90 & 100 \\
\hline $\mathrm{A}_{3} \mathrm{~B}_{3} \mathrm{C}_{2}$ & 0.3 & 425 & 20 & 80 & 100 \\
\hline $\mathrm{A}_{0} \mathrm{~B}_{2} \mathrm{C}_{2}$ & 0 & 250 & 20 & 80 & 100 \\
\hline Epoxy & 0 & 0 & 0 & 100 & 100 \\
\hline
\end{tabular}

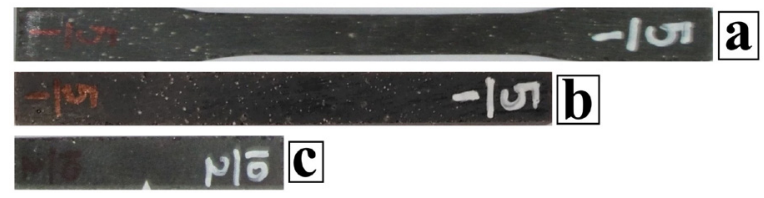

Fig. 3. a) Tensile test specimen, b) flexural test specimen, and c) impact test specimen

\section{SPECIMEN TESTING}

Specimens of dimensions $165 \mathrm{~mm} \times 12.7 \mathrm{~mm} \times 3$ $\mathrm{mm}$ were subjected to tensile test as per ASTM D638 using a SHIMADZU universal testing machine. Dogbone shaped specimens of $19 \mathrm{~mm}$ width at the widest section and $12.7 \mathrm{~mm}$ width at the narrow section, 115 $\mathrm{mm}$ gauge length and cross-head speed of $50 \mathrm{~mm} / \mathrm{min}$ were used for this test. Specimens of dimensions 127 $\mathrm{mm} \times 12.7 \mathrm{~mm} \times 3 \mathrm{~mm}$ were subjected to three-point bend type flexural test as per ASTM D790 using an INSTRON universal testing machine. A cross-head speed of $2.6 \mathrm{~mm} / \mathrm{min}$ and a span length of sixteen times the thickness of the specimen were used for this test. Specimens of dimensions $63.5 \mathrm{~mm} \times 12.7$ $\mathrm{mm} \times 3 \mathrm{~mm}$ with a "V" notch depth of $2.54 \mathrm{~mm}$ and notch angle of $45^{\circ}$ was used for conducting an Izod impact test as per ASTM D256 using a Tinius Olsen impact testing machine. Three replicate specimens were used for each test and the data reported are the average of these three tests. A JEOL scanning electron microscope was used for imaging the tensile tested specimens. All specimens were examined using an accelerating voltage of $3.0 \mathrm{kV}$ power supply.

\section{GREY RELATIONAL ANALYSIS}

Grey relational analysis (GRA) was used for solving the interrelationship among the multiple responses. In this approach a grey relational grade was obtained for analysing the relational degree of the multiple responses. Original response data was obtained by conducting experiments at different levels of factors based on an orthogonal array. The responses were transformed into signal to noise $(\mathrm{S} / \mathrm{N})$ ratio. The term "signal" represents the desirable value and the term "noise" represents the undesirable value. The formulae for $\mathrm{S} / \mathrm{N}$ ratio are designed such that larger factor level settings can be selected to optimize the quality characteristics of an experiment. The method of calculating the $\mathrm{S} / \mathrm{N}$ ratio depends on whether the quality characteristic has smaller-the better, largerthe better and nominal-the best formulation. S/N ratios were transformed into normalized $\mathrm{S} / \mathrm{N}$ ratios using appropriate formulae depending on the type of quality characteristics to avoid the effect of using different units and to reduce variability. Grey relational coefficients for the normalized $\mathrm{S} / \mathrm{N}$ ratios were computed. Grey relational grades that represent the level of correlation between reference sequence and comparability sequence were determined. Using ANOVA, the contribution of influencing factors was obtained using grey relational grades.

\section{RESULTS AND DISCUSSION}

\subsection{Properties of Pure Horn}

Scanning electron microscopy (SEM) with an EDX test conducted on horn specimen reveals that the major elements present in horn are carbon, oxygen, nitrogen and molybdenum with a maximum carbon weight percentage of 59.03 [4]. Ultimate tensile strength, tensile modulus, elongation percentage at break, flexural strength, flexural modulus, impact strength, compression strength, hardness, density, extrapolated onset temperature $\left(T_{o}\right)$ and first derivative peak temperature $\left(T_{p}\right)$ of pure horn specimen are 41.86 $\mathrm{MPa}, 806.33 \mathrm{MPa}, 5.04 \%$, $122.9 \mathrm{MPa}, 4515.30 \mathrm{MPa}$, $136.70 \mathrm{~J} / \mathrm{m}, 70.68 \mathrm{MPa}, 86 \mathrm{HRL}, 1304 \mathrm{~kg} / \mathrm{m}^{3}, 225^{\circ} \mathrm{C}$ and $507^{\circ} \mathrm{C}$, respectively [4]. The stress-strain diagram of pure horn specimen and the values of elongation percentage at break shows that the horn is brittle [4]. As the HP is of lower density and the mechanical and thermal properties of horn are better than polymers, use of HP particles as filler with polymers will enhance the properties. 


\subsection{Properties of HP/Epoxy Composites}

Table 3 shows the mechanical properties of HP/epoxy composites and neat epoxy specimens. Table 4 shows the $\mathrm{S} / \mathrm{N}$ ratios for mechanical properties of HP/epoxy composites. Larger-the better quality characteristics was used for ultimate tensile strength, tensile modulus, elongation percentage at break, flexural strength, flexural modulus and impact strength to withstand external forces. The formula to calculate larger-the better $\mathrm{S} / \mathrm{N}$ ratio is: $\mathrm{S} / \mathrm{N}=-10 \times \log \left(1 / Y^{2}\right)$ where, $Y$ is the output (response) of the experiment. Fig. 4 shows the main effects plots for $\mathrm{S} / \mathrm{N}$ ratios of various properties obtained using MINITAB software. The main effects plot, graphs the $\mathrm{S} / \mathrm{N}$ ratio for each factor level, connected by a line. When the line is horizontal, there is no main effect present. When the line is steeper, then different levels of the factor affect the response differently.

\subsubsection{Ultimate Tensile Strength}

The tensile strength of a particle-reinforced polymer matrix composite is based on effective load transfer between the matrix and the particles. Factors such as good bonding strength between fibre particles and resin, particle size and particle loading affect the strength [6]. The bonding can be enhanced by alkali treatment of fibre surfaces [5]. From Fig. 4a, it is observed that an increase in $\mathrm{NaOH}$ concentration $\left(A_{3}\right)$ increases ultimate tensile strength because alkali treatment increases bonding strength. Smaller-sized particles have better dispersion, high surface area with the matrix, and the smallest HP size $\left(B_{1}\right)$ thus gives increased strength. Powder loading decreases strength due to clustering of particles and thus the lowest HP volume percentage $\left(C_{1}\right)$ gives high strength. From Fig. $4 \mathrm{a}$, it is also observed that HP volume percentage influences better than HP size does, whereas $\mathrm{NaOH}$ concentration has no significant influence.

\subsubsection{Tensile Modulus}

Tensile modulus of a particle-reinforced polymer matrix composite is enhanced by adding high-stiffness particles to the polymer matrix. Tensile modulus is dependent on fibre loading but independent of particle size and interfacial adhesion [6]. Tensile modulus is

Table 3. Mechanical properties of HP/epoxy composites and neat epoxy specimens

\begin{tabular}{cccccccc}
\hline Trial No. & Trial ID & $\begin{array}{c}\text { Ultimate tensile } \\
\text { strength }[\mathrm{MPa}]\end{array}$ & $\begin{array}{c}\text { Tensile modulus } \\
{[\mathrm{MPa}]}\end{array}$ & $\begin{array}{c}\text { Elongation } \% \\
\text { at break [\%] }\end{array}$ & $\begin{array}{c}\text { Flexural strength } \\
{[\mathrm{MPa}]}\end{array}$ & $\begin{array}{c}\text { Flexural modulus } \\
{[\mathrm{MPa}]}\end{array}$ & $\begin{array}{c}\text { Impact strength } \\
{[\mathrm{kJ} / \mathrm{m} \text { [ }]}\end{array}$ \\
\hline 1 & $\mathrm{~A}_{1} \mathrm{~B}_{1} \mathrm{C}_{1}$ & 29.42 & 1069.83 & 3.41 & 49.39 & 3558.07 & 0.802 \\
\hline 2 & $\mathrm{~A}_{1} \mathrm{~B}_{2} \mathrm{C}_{2}$ & 21.65 & 870.82 & 2.68 & 34.86 & 3020.28 & 0.771 \\
\hline 3 & $\mathrm{~A}_{1} \mathrm{~B}_{3} \mathrm{C}_{3}$ & 16.75 & 605.08 & 1.86 & 23.29 & 2791.78 & 0.686 \\
\hline 4 & $\mathrm{~A}_{2} \mathrm{~B}_{1} \mathrm{C}_{2}$ & 23.32 & 975.56 & 2.81 & 37.82 & 3258.04 & 0.745 \\
\hline 5 & $\mathrm{~A}_{2} \mathrm{~B}_{2} \mathrm{C}_{3}$ & 19.56 & 658.5 & 2.18 & 28.93 & 2912.28 & 0.615 \\
\hline 6 & $\mathrm{~A}_{2} \mathrm{~B}_{3} \mathrm{C}_{1}$ & 24.99 & 983.51 & 3.02 & 38.24 & 3206.05 & 1.168 \\
\hline 7 & $\mathrm{~A}_{3} \mathrm{~B}_{1} \mathrm{C}_{3}$ & 20.55 & 778.31 & 2.39 & 32.85 & 2907.24 & 0.568 \\
\hline 8 & $\mathrm{~A}_{3} \mathrm{~B}_{2} \mathrm{C}_{1}$ & 28.29 & 1052.68 & 3.17 & 44.66 & 3536.04 & 1.084 \\
\hline 9 & $\mathrm{~A}_{3} \mathrm{~B}_{3} \mathrm{C}_{2}$ & 22.15 & 802.47 & 2.59 & 31.37 & 3108.8 & 0.958 \\
\hline 10 & $\mathrm{~A}_{0} \mathrm{~B}_{2} \mathrm{C}_{2}$ & 15.51 & 585.38 & 2.65 & 51.25 & 6017.87 & 0.761 \\
\hline 11 & $\mathrm{Epoxy}$ & 42.56 & 2076.52 & 3.54 & 56.82 & 3640.34 & 0.721 \\
\hline
\end{tabular}

Table 4. S/N ratios of mechanical properties of HP/epoxy composites

\begin{tabular}{cccccccc}
\hline Trial No. & Trial ID & $\begin{array}{c}\text { Ultimate tensile } \\
\text { strength }\end{array}$ & Tensile modulus & $\begin{array}{c}\text { Elongation } \\
\text { \% at break }\end{array}$ & Flexural strength & Flexural modulus & Impact strength \\
\hline 1 & $\mathrm{~A}_{1} \mathrm{~B}_{1} \mathrm{C}_{1}$ & 29.37 & 60.59 & 10.66 & 33.87 & 71.02 & -1.92 \\
\hline 2 & $\mathrm{~A}_{1} \mathrm{~B}_{2} \mathrm{C}_{2}$ & 26.71 & 58.80 & 8.56 & 30.85 & 69.60 & -2.26 \\
\hline 3 & $\mathrm{~A}_{1} \mathrm{~B}_{3} \mathrm{C}_{3}$ & 24.48 & 55.64 & 5.39 & 27.34 & 68.92 & -3.27 \\
\hline 4 & $\mathrm{~A}_{2} \mathrm{~B}_{1} \mathrm{C}_{2}$ & 27.35 & 59.79 & 8.97 & 31.55 & 70.26 & -2.56 \\
\hline 5 & $\mathrm{~A}_{2} \mathrm{~B}_{2} \mathrm{C}_{3}$ & 25.83 & 56.37 & 6.77 & 29.23 & 69.28 & -4.22 \\
\hline 6 & $\mathrm{~A}_{2} \mathrm{~B}_{3} \mathrm{C}_{1}$ & 27.96 & 59.86 & 9.60 & 31.65 & 70.12 & 1.35 \\
\hline 7 & $\mathrm{~A}_{3} \mathrm{~B}_{1} \mathrm{C}_{3}$ & 26.26 & 57.82 & 7.57 & 30.33 & 69.27 & -4.91 \\
\hline 8 & $\mathrm{~A}_{3} \mathrm{~B}_{2} \mathrm{C}_{1}$ & 29.03 & 60.45 & 10.02 & 33.00 & 70.97 & 0.70 \\
\hline 9 & $\mathrm{~A}_{3} \mathrm{~B}_{3} \mathrm{C}_{2}$ & 26.91 & 58.09 & 8.27 & 29.93 & 69.85 & -0.37 \\
\hline
\end{tabular}


also affected by clustering of particles and de-bonding at high fibre loading. From Fig. 4b, it is observed that increase in $\mathrm{NaOH}$ concentration $\left(\mathrm{A}_{3}\right)$ increases tensile modulus because alkali treatment increases roughness and hardness of HP surfaces and thus offers resistance to movement of particles. Smaller particles have better dispersion, high surface area with the matrix and thus, the smallest HP size $\left(\mathrm{B}_{1}\right)$ gives increased tensile modulus. Powder loading increases clustering of particles and reduces tensile modulus. Thus, the lowest HP volume percentage $\left(\mathrm{C}_{1}\right)$ gives the highest tensile modulus. From Fig. $4 \mathrm{~b}$, it is also observed that $\mathrm{NaOH}$ concentration does not have significant influence, whereas HP volume percentage influences more than HP size does.

\subsubsection{Elongation percentage at Break}

From Fig. 4c, it is observed that increase in $\mathrm{NaOH}$ concentration $\left(\mathrm{A}_{3}\right)$ increases elongation percentage at the break because alkali treatment increases roughness and hardness of HP surfaces and thus increases bonding between the particles. Larger sized HP particles $\left(\mathrm{B}_{3}\right)$ offer more resistance to movement and thus decrease the elongation percentage at break. As HP particles are brittle, an increase in HP loading
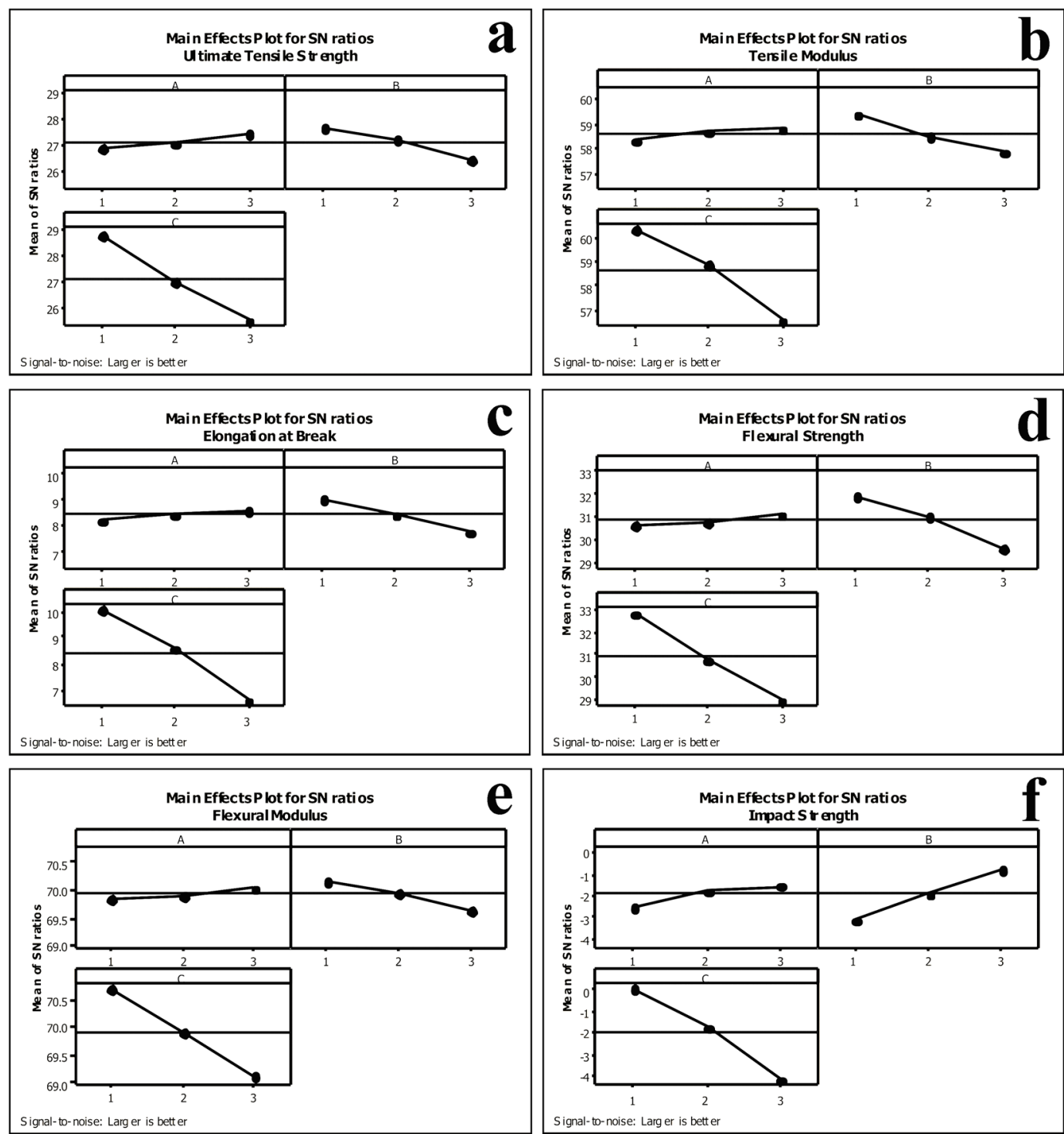

Fig. 4. Main effects plots for $S / N$ ratios of a) ultimate tensile strength, b) tensile modulus, c) elongation $\%$ at break, d) flexural strength, e) flexural modulus and f) impact strength 
increases the brittleness and clustering of particles and thus reduces the elongation percentage at break. Thus, the lowest HP volume percentage $\left(\mathrm{C}_{1}\right)$ gives the highest elongation percentage at break. From Fig. $4 \mathrm{c}$, it is also observed that $\mathrm{NaOH}$ concentration and HP size do not influence greatly, whereas HP volume percentage has more influence.

\subsubsection{Flexural Strength}

Flexural strength of particle-reinforced polymer matrix composite is affected by factors such as the bonding strength between the particles and the matrix, size of the particles and particle loading [6]. From Fig. 4d, it is observed that increase in $\mathrm{NaOH}$ concentration $\left(\mathrm{A}_{3}\right)$ increases flexural strength because alkali treatment increases bonding strength. Smaller particles have better dispersion, high surface area with the matrix and thus the smallest HP size $\left(\mathrm{B}_{1}\right)$ gives better flexural strength. Powder loading increases clustering of particles and reduces flexural strength. Thus, the lowest HP volume percentage $\left(\mathrm{C}_{1}\right)$ gives the highest flexural strength. From Fig. 4d, it is also observed that $\mathrm{NaOH}$ concentration does not have significant influence, whereas HP volume percentage has more influence than HP size.

\subsubsection{Flexural Modulus}

Flexural modulus of a particle-reinforced polymer matrix composite depends on the fibre loading but is not affected by particle size and interfacial adhesion [6]. From Fig. 4e, it is observed that increase in $\mathrm{NaOH}$ concentration $\left(\mathrm{A}_{3}\right)$ increases flexural modulus because alkali treatment increases roughness and hardness of HP surfaces and thus offers resistance to movement of particles. Smaller particles have better dispersion, high surface area with the matrix and thus the smallest HP size $\left(B_{1}\right)$ gives increased flexural modulus. Powder loading increases clustering of particles and reduces flexural modulus. Thus, the lowest HP volume percentage $\left(\mathrm{C}_{1}\right)$ gives the highest flexural modulus. From Fig. 4e, it is also observed that $\mathrm{NaOH}$ con. does not influence greatly, whereas HP volume percentage influences better than HP size.

\subsubsection{Impact Strength}

From Fig. 4f, it is observed that increase in $\mathrm{NaOH}$ concentration $\left(A_{3}\right)$ increases impact strength because alkali treatment increases bonding strength. Larger sized particles $\left(B_{3}\right)$ offer more resistance to movement and thus increase impact strength. As HP particles are brittle, any increase in HP loading increases brittleness and clustering of particles and thus reduces impact strength. Thus, the lowest HP volume percentage $\left(C_{1}\right)$ gives the highest impact strength. From Fig. 4f, it is also observed that $\mathrm{NaOH}$ concentration does not have significant influence, whereas HP volume percentage influences better than HP size does.

From Table 3, it can be observed that the properties of HP/epoxy composites are less than the properties of virgin epoxy specimens. This is because HP particles in epoxy resin acts as stress concentration points and creates weakness in the adhesive force between HP particles and the resin. Clustering of HP problem and increase in brittleness with increase in powder loading are also the reasons for decreased mechanical properties of the composites. An agglomeration problem can also be observed from Fig. 6, the SEM images of tensile tested specimens.

Table 5. Grey relational grades of trials

\begin{tabular}{lccccc}
\hline Trials & $\mathrm{A}_{1} \mathrm{~B}_{1} \mathrm{C}_{1}$ & $\mathrm{~A}_{1} \mathrm{~B}_{2} \mathrm{C}_{2}$ & $\mathrm{~A}_{1} \mathrm{~B}_{3} \mathrm{C}_{3}$ & $\mathrm{~A}_{2} \mathrm{~B}_{1} \mathrm{C}_{2}$ & $\mathrm{~A}_{2} \mathrm{~B}_{2} \mathrm{C}_{3}$ \\
\hline GRG & 0.915 & 0.504 & 0.345 & 0.587 & 0.389 \\
\hline & & & & & \\
\hline Trials & $\mathrm{A}_{2} \mathrm{~B}_{3} \mathrm{C}_{1}$ & $\mathrm{~A}_{3} \mathrm{~B}_{1} \mathrm{C}_{3}$ & $\mathrm{~A}_{3} \mathrm{~B}_{2} \mathrm{C}_{1}$ & $\mathrm{~A}_{3} \mathrm{~B}_{3} \mathrm{C}_{2}$ & \\
\hline GRG & 0.709 & 0.427 & 0.866 & 0.515 & \\
\hline
\end{tabular}

Table 6. Mean of grey relational grades

\begin{tabular}{lcccc}
\hline Factors & Level1 & Level2 & Level3 & Max-Min \\
\hline NaOH con. (A) & 0.588 & 0.562 & 0.603 & 0.041 \\
\hline HP size (B) & 0.643 & 0.586 & 0.523 & 0.120 \\
\hline HP vol. \% (C) & 0.830 & 0.536 & 0.387 & 0.443 \\
\hline
\end{tabular}

Table 5 shows the grey relational grades (GRG) of trials of $\mathrm{L}_{9}$ orthogonal array. Table 6 shows the mean of grey relational grades. From Table 6 , it can be observed that the mean of grades for the trial $A_{3} B_{1} C_{1}$ were found to be higher and is the optimum specimen. This is because alkali treatment makes the HP surfaces hard and rough and increases bonding strength. It is also observed that $\mathrm{NaOH}$ treated composites have improved properties than the untreated composites do. Therefore, $\mathrm{NaOH}$ concentration $\left(\mathrm{A}_{3}\right.$ i.e., $\left.0.3 \mathrm{~N}\right)$ is found to be optimum. Smaller particles are desired for most of the mechanical properties, whereas bigger sized particles are desired for impact strength. Considering all the properties, smaller particles $\left(B_{1}\right.$ i.e., $125 \mu \mathrm{m})$ are found to be optimal. Increase in powder loading increases clustering of the powder particles leading to surface cracks and incompatibility and thus affects the properties. This can be observed very well from SEM micrographs of tensile tested specimens. Thus, when the HP volume percentage 
is the smallest ( $\mathrm{C} 1$ i.e., $10 \%)$ good compatibility between ingredients and epoxy resin is obtained leading to an optimal result. Fig. 5 shows the graphs of main effects plot for grey relational grades. From Fig. 5, it can also be observed that $\mathrm{A}_{3} \mathrm{~B}_{1} \mathrm{C}_{1}$ is an optimal specimen.

\subsection{Scanning Electron Microscopy}

Fig. 6 shows the SEM images of the tensile-tested specimens taken at a magnification of $250 \times$, at a scale of $100 \mu \mathrm{m}$ and at an accelerating voltage of $3.0 \mathrm{kV}$. Fig. $6 \mathrm{a}$ to $\mathrm{i}$ show the SEM images of the specimens of Taguchi $\mathrm{L}_{9}$ orthogonal array. From Fig. 6a, $d$ and $\mathrm{g}$, which shows the SEM images of specimens with the smallest HP particle size (i.e., $B_{1}=125 \mu \mathrm{m}$ ), it is found that good compatibility exists between the HP and the resin. This is because smaller particles have high surface area with the matrix and thus increases compatibility [6]. From Fig. 6c, f and i, which shows the SEM images of specimens with the highest HP volume percentage(i.e., $\mathrm{C}_{3}=30 \%$ ), it can also be observed that when the volume percentage of HP increases, clustering of particles takes place leading to incompatibility between the particles and the resin. From Fig. 6j, which shows the SEM image of the specimen $\mathrm{A}_{0} \mathrm{~B}_{2} \mathrm{C}_{2}$, the specimen with untreated $\mathrm{HP}$, it can be observed that poor compatibility exists
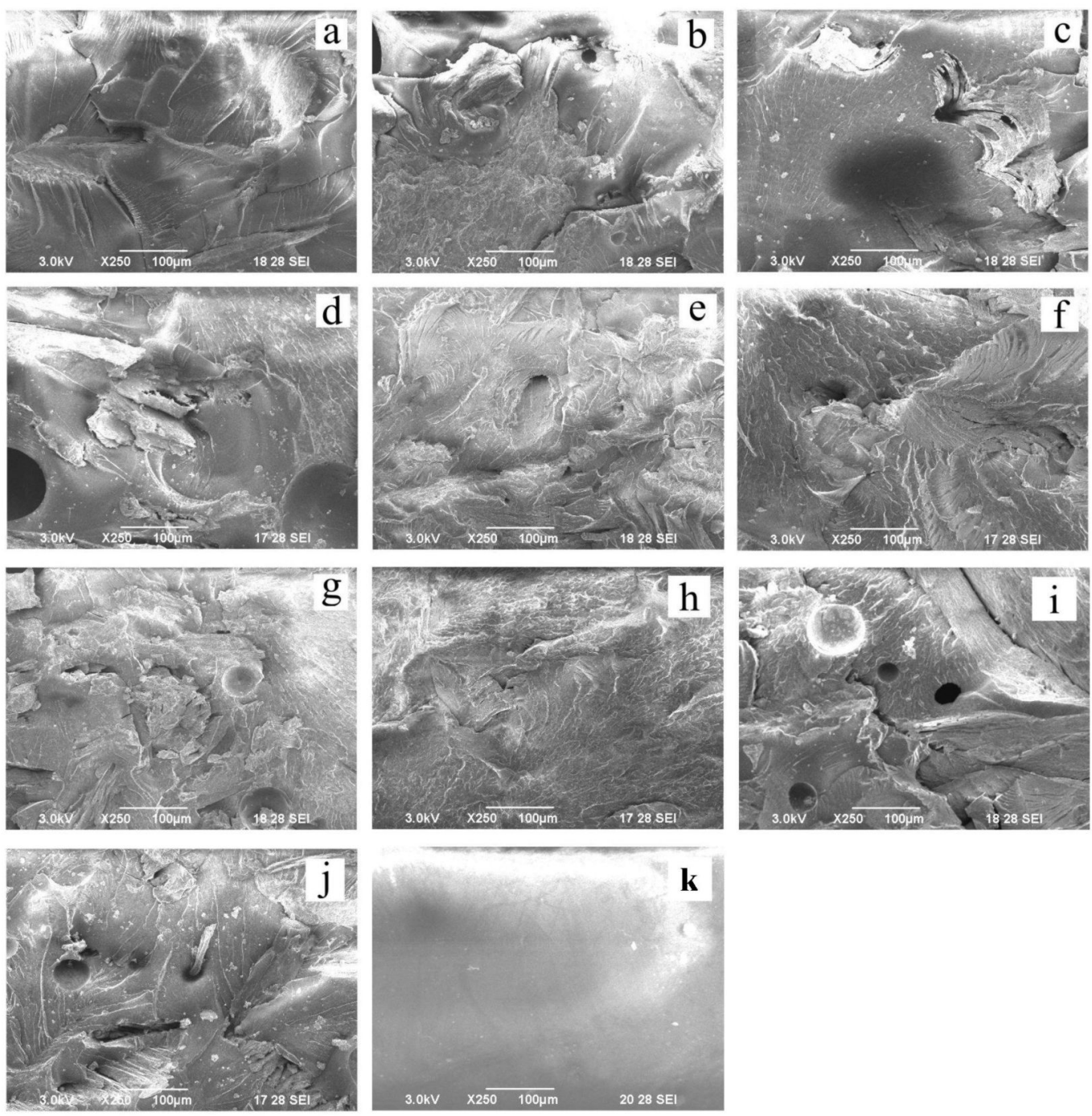

Fig. 6. SEM micrographs of tensile tested surfaces of specimens taken at a magnification of 250x, at a scale of $100 \mu \mathrm{m}$ and at an accelerating voltage of $3 \mathrm{kV}$; a) $A_{1} B_{1} C_{1}$, b) $A_{1} B_{2} C_{2}$, c) $A_{1} B_{3} C_{3}$, d) $A_{2} B_{1} C_{2}$, e) $A_{2} B_{2} C_{3}$, f) $A_{2} B_{3} C_{1}$, g) $A_{3} B_{1} C_{3}$, h) $A_{3} B_{2} C_{1}$, i) $A_{3} B_{3} C_{2}$, j) untreated $\mathrm{HP}$ specimen $\mathrm{A}_{0} \mathrm{~B}_{2} \mathrm{C}_{2}$ and $k$ ) neat epoxy specimen 
between the HP and the resin. From Fig. 6k, which shows the SEM image of the neat epoxy specimen, it can be observed that it is plain without any blow holes or surface cracks, due to the absence of HP particles.

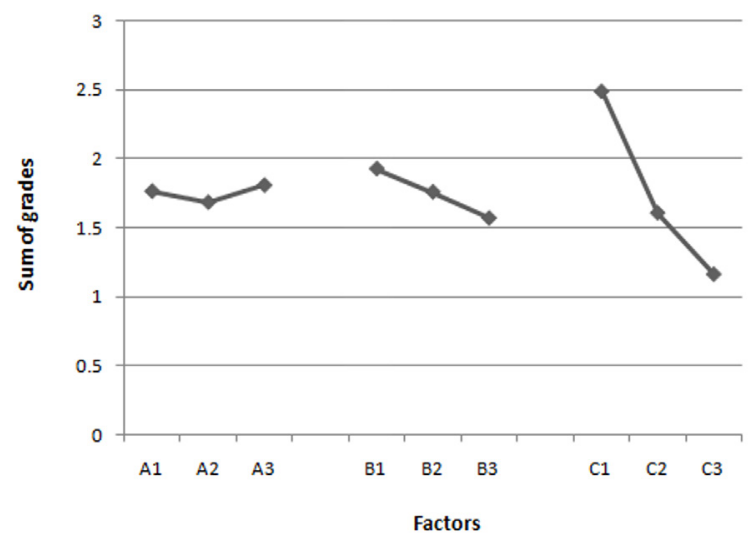

Fig. 5. Graphs of main effects plot for grey relational grades

Table 7. ANOVA table for the grey relational grades of trials

\begin{tabular}{lccccc}
\hline Factors & DOF & $\begin{array}{c}\text { Sum of } \\
\text { Squares }\end{array}$ & $\begin{array}{c}\text { Mean } \\
\text { Square }\end{array}$ & F Value & \% Contribution \\
\hline $\mathrm{NaOH}$ con. & 2 & 0.003 & 0.001 & 0.41 & 0.78 \\
\hline HP size & 2 & 0.022 & 0.011 & 3.37 & 6.43 \\
\hline HP vol. \% & 2 & 0.305 & 0.153 & 47.56 & 90.87 \\
\hline Error & 2 & 0.006 & 0.003 & & 1.91 \\
\hline Total & 8 & 0.336 & & & 100.00 \\
\hline
\end{tabular}

Table 7 shows the ANOVA table obtained for the grey relational grades of properties used to find the significant factor and percentage contribution of influencing factors. From the ANOVA table, it is observed that the major influencing factor is HP volume percentage with $90.87 \%$, the moderate influencing factor is HP size with $6.43 \%$ and the least influencing factor is $\mathrm{NaOH}$ concentration with $0.78 \%$. This is due to the fact that when the HP volume percentage is increased, the compatibility between the HP particles and matrix interface is lost and this influences better than $\mathrm{HP}$ size and $\mathrm{NaOH}$ concentration. Table 8 shows the $\mathrm{R}$ squared and $\mathrm{R}$ squared adjusted values of mechanical properties of horn powder-filled epoxy composites. From Table 8, it can be observed that most of the values are above 95 $\%$, confirming to $95 \%$ confidence level.

\section{CONCLUSION}

Particle-filled composites are developed using bio-waste HP and epoxy resin. Mechanical and morphological properties, such as tensile strength, tensile modulus, elongation percentage at break, flexural strength, flexural modulus, impact strength and microstructure of the specimens were investigated.

Optimization of various factors was done using GRA and ANOVA, and the results were compared with the untreated HP specimens. From GRA, optimum factor levels were found to be $0.3 \mathrm{~N} \mathrm{NaOH}$ concentration $\left(\mathrm{A}_{3}\right), 125 \mu \mathrm{m}$ sized HP particles $\left(\mathrm{B}_{1}\right)$ and $10 \%$ volume of HP particles $\left(\mathrm{C}_{1}\right)$. From ANOVA, it is observed that the major influencing factor is HP volume percentage with $90.87 \%$, the moderate influencing factor is HP size with $6.43 \%$, the least influencing factor is $\mathrm{NaOH}$ concentration with $0.78 \%$ and the error percentage is found to be $1.91 \%$.

From SEM images of the tensile tested specimens, it can be observed that when the particle size increases, surface area with the matrix decreases and thus decrease the compatibility. Furthermore, when the HP volume percentage increases clustering of particles takes place leading to incompatibility between the particles and the resin.

From the $\mathrm{R}$ squared and $\mathrm{R}$ squared adjusted values of the properties, it can be observed that most of the values are above $95 \%$, confirming to $95 \%$ confidence level. Comparing the optimum specimen $\mathrm{A}_{3} \mathrm{~B}_{1} \mathrm{C}_{1}$ with the untreated HP specimen $\mathrm{A}_{0} \mathrm{~B}_{2} \mathrm{C}_{2}$, optimum specimen has better properties and hence, $\mathrm{HP} /$ epoxy composites can find applications in various sectors.

As the filler is derived from bio-waste, this work is innovative. Use of bio-waste filler for composite manufacturing reduces environmental pollution and is also cost effective.

\section{ACKNOWLEDGEMENTS}

The authors would like to thank Anna University Chennai, Tamilnadu, India, Central Institute of Plastics Engineering and Technology, Chennai, Tamilnadu, India, Alagappa Chettiar College of Engineering and Technology, Karaikudi, Tamilnadu, India and Karunya

Table 8. $R$ squared and $R$ squared adjusted values of mechanical properties

\begin{tabular}{lcccccc}
\hline Param.eters & $\begin{array}{c}\text { Ultimate tensile } \\
\text { strength }\end{array}$ & $\begin{array}{c}\text { Tensile } \\
\text { modulus }\end{array}$ & $\begin{array}{c}\text { Elongation } \\
\% \text { at break }\end{array}$ & $\begin{array}{c}\text { Flexural } \\
\text { strength }\end{array}$ & $\begin{array}{c}\text { Flexural } \\
\text { modulus }\end{array}$ & $\begin{array}{c}\text { Impact } \\
\text { strength }\end{array}$ \\
\hline R squared [\%] & 96.4 & 98.0 & 98.7 & 98.0 & 92.0 & 97.9 \\
\hline R squared adjusted [\%] & 94.2 & 96.8 & 98.0 & 96.7 & 87.2 & 96.7 \\
\hline
\end{tabular}


University, Coimbatore, Tamilnadu, India for the manufacturing and testing of specimens. The authors also would like to thank the Management and the Department of Mechanical Engineering of C. Abdul Hakeem College of Engineering and Technology, Melvisharam-632509, Vellore District, Tamilnadu, India.

\section{REFERENCES}

[1] Sisson, S. (1930). The Anatomy of the Domestic Animals. W.B. Saunders Company, Philadelphia.

[2] Meyers, M.A., Chen, P.-Y., Lin, A.Y.-M., Seki, Y. (2008). Biological materials: Structure and mechanical properties. Progress in Materials Science, vol. 53, no. 1, p. 1-206, D0l:10.1016/j. pmatsci.2007.05.002.

[3] Rizvi, T.Z., Khan, M.A. (2008). Temperature-dependent dielectric properties of slightly hydrated horn keratin. International Journal of Biological Macromolecules, vol. 42, no. 1, p. 292-297, D0l:10.1016/j.jjbiomac.2008.01.001.

[4] Kumar, D., Rajendra Boopathy, S. (2014). Mechanical and thermal properties of horn fibre reinforced polypropylene composites. Procedia Engineering, vol. 97, p. 648-659, D0I:10.1016/J.proeng.2014.12.294.

[5] Venkateshwaran, N., Elaya Perumal, A., Arunsundaranayagam, D. (2013). Fibre surface treatment and its effect on mechanical and visco-elastic behaviour of banana/epoxy composite. Materials and Design, vol. 47, p. 151-159, DOI:10.1016/j.matdes.2012.12.001.

[6] Fu, S.-Y., Feng, X.-Q., Lauke, B., Mai, Y.-W. (2008). Effects of particle size, particle/matrix interface adhesion and particle loading on mechanical properties of particulate-polymer composites. Composites: Part B: Engineering, vol. 39, no. 6, p. 933-961, D0l:10.1016/j.compositesb.2008.01.002.

[7] Ku, H., Wang, H., Pattarachaiyakoop, N., Trada, M. (2011). A review on the tensile properties of natural fibre reinforced polymer composites. Composites Part B: Engineering, vol. 42, no. 4, p. 856-873, D0I:10.1016/j.compositesb.2011.01.010.

[8] Mishra, S.C., Nayak, N.B., Satapathy, A. (2010). Investigation on bio-waste reinforced epoxy composites. Journal of Reinforced Plastics and Composites, vol. 29, no. 19, p. 30163020, Dol:10.1177/0731684408100740.

[9] Girisha, C., Sanjeevamurthy, Srinivas, G.R. (2012). Sisal/ coconut coir natural fibres-epoxy composites: Water absorption and mechanical properties. International Journal of Engineering and Innovative Technology, vol. 2, no. 3, p. 166-170.

[10] Blau, P.J. (2001). Compositions, functions, and testing of friction brake materials and their additives. Oak Ridge National Laboratory Technical Report, ORNL/TM-2001/64, Oak Ridge, Dol:10.2172/788356.
[11] Deo, C., Acharya, S.K. (2010). Effects of fibre content on abrasive wear of Lantana Camara fibre reinforced polymer matrix composite. Indian Journal of Engineering and Materials Sciences, vol. 17, p. 219-223.

[12] Olokode, O.S., Fakolujo, S.O., Aiyedun, P.O., Jaji, Z.O., Owoeye, F.T., Anyanwu, B.U. (2012). Experimental study on the morphology of keratin based material for asbestos free brake pad. Journal of Basic \& Applied Sciences, vol. 8, no. 2, p. 302308, D0I:10.6000/1927-5129.2012.08.02.08.

[13] Antaryami, M. (2014). Investigations on wear characteristics of teak wood dust filled epoxy composites. Journal of Production Engineering, vol. 17, no. 1, p. 75-78.

[14] Zhan, M., Wool, P.R., Xiao, J.Q. (2011). Electrical properties of chicken feather fibre reinforced epoxy composites. Composites Part A: Applied Science and Manufacturing, vol. 42, no. 3, p. 229-233, DOI:10.1016/j.compositesa.2010.11.007.

[15] Mishra, S.C., Nayak, N.B. (2010). An investigation of dielectric properties of chicken feather reinforced epoxy matrix composite. Journal of Reinforced Plastics and Composites, vol. 29, no. 17, p. 2691-2697, D0I:10.1177/0731684409356610.

[16] Krishnaiah, K., Shahabudeen, P. (2012). Applied Design of Experiments and Taguchi Methods, PHI Learning Private Limited, New Delhi.

[17] Fung, C.P. (2003). Manufacturing process optimization for wear property of fibre-reinforced polybutylene terephthalate composites with grey relational analysis. Wear, vol. 254, no. 3-4, p. 298-306, D0I:10.1016/S0043-1648(03)00013-9.

[18] Hasani, H., Tabatabaei, S.A., Amiri, G. (2012). Grey relational analysis to determine the optimum process parameters for open-end spinning yarns. Journal of Engineered Fibres and Fabrics, vol. 7, no. 2, p. 81-86.

[19] Sui, G., Jana, S., Salehi-khojin, A., Neema, S., Zhong, W.H., Chen, H.,Huo, Q. (2008). Thermal and mechanical properties of epoxy composites reinforced by natural hydrophobic sand. Journal of Applied Polymer Science, vol. 109, no. 1, p. $247-$ 255, DOI:10.1002/app.27321.

[20] Ozsoy, I., Demirkol, A., Mimaroglu, A., Unal, H., Demir, Z. (2015).The influence of micro- and nano-filler content on the mechanical properties of epoxy composites. Strojniški vestnik - Journal of Mechanical Engineering, vol. 61, no. 10, p. 601609, D0I:10.5545/sv-jme.2015.2632.

[21] Croccolo, D., De Agostinis, M., Fini, S., Liverani, A., Marinelli, N., Nisini, E., Olmi, G. (2015). Mechanical characteristics of two environmentally friendly resins reinforced with flax fibers. Strojniški vestnik - Journal of Mechanical Engineering, vol. 61, no. 4, p. 227-236, D0l:10.5545/sv-jme.2014.2248.

[22] Valasek, P., Muller, M. (2015). Abrasive wear in three-phase waste-based polymeric particle composites. Tehnički vjesnik - Technical gazette, vol. 22. 2, p. 257-262, Dol:10.17559/TV20130905190904.

[23] Valasek, P., Muller, M., Hloch, S.(2015). Recycling of corundum particles-two-body abrasive wear of polymeric composites based on waste. Tehnički vjesnik - Technical gazette, vol. 22, no. 3, p. 567-572, DOI:10.17559/TV-20131111140048. 